\title{
Gagal ginjal kronis pada Kucing Domestik Rambut Pendek
}

\author{
(Chronic Kidney Disease in Domestic Shorthair Cat)
}

\author{
Ovi Prudenta ${ }^{1}$, Arnes Mardasella ${ }^{1 *}$, Dina Sahmiranda ${ }^{1}$, Yudi Ardianto ${ }^{1}$, Ajeng Aeka ${ }^{2}$ \\ 1Program Studi Pendidikan Profesi Dokter Hewan, Fakultas Kedokteran Hewan, Universitas \\ Brawijaya, Malang \\ ${ }^{2}$ Bagian Klinik Hewan dan Rumah Sakit Hewan Pendidikan Fakultas Kedokteran Hewan, \\ Universitas Brawijaya, Malang \\ *email: arnes.mardasella@gmail.com
}

\begin{abstract}
ABSTRAK
Gagal ginjal kronis adalah gangguan fungsi ginjal yang progresif dan irreversible. Pada kondisi ini ginjal gagal mempertahankan fungsi metabolisme serta keseimbangan cairan dan elektrolit, sehingga menyebabkan uremia. Seekor kucing domestik jantan berumur \pm 3 tahun dengan bobot 2,15 Kg diperiksa dengan keluhan letargi, bulu kotor dan kusam, bersin, dehidrasi, poliuri, polidipsi, membrana mukosa pucat, anoreksia serta ulserasi mulut. Pemeriksaan hematology menunjukkan hasil anemia, leukositosis, neutrofilia, trombositopenia, limfopenia, peningkatan nilai MCV, penurunan nilai MCHC. Pemeriksaan kimia darah menunjukkan hasil peningkatan kreatinin dan BUN. Pemeriksaan natif ditemukan adanya telur cacing. Hewan didiagnosa gagal ginjal kronis. Penanganan pada kasus ini diberikan terapi antibiotik Claneksi dan antibiotik Doxycycline, mukolitik Fluimucil, antianemik hematodin, obat antiparasit (Praziquantel, Pyrantel pamoat), serta supementasi tambahan berupa imboost, madu, minyak ikan serta pakan renal. Pada post terapi hewan terlihat membaik, gagal ginjal kronis tidak dapat disembuhkan sehingga diperlukan manajemen pengobatan dan diet yang tepat untuk dapat memperbaiki kualitas hidup dan memperpanjang hidup hewan.
\end{abstract}

Kata kunci: Gagal ginjal kronis, gejala klinis, pengobatan, diet

\begin{abstract}
Chronic kidney disease is a progressive impairment of renal function and irreversible. The kidneys fail to maintain metabolism and fluid and electrolyte balance, causing uremia. An \pm 3 years and weighing $2.15 \mathrm{~kg}$ of male domestic cat was presented with lethargy, dirty and dull hair, sneezing, dehydration, polyuria, polydipsia, pale mucosal membranes, anorexia and mouth ulceration. Hematological examination was presented the results of anemia, leukocytosis, neutrophilia, thrombocytopenia, lymphopenia, increased MCV value, decreased MCHC value. Blood chemistry examination was presented the results of creatinine and BUN. Native examination found worm eggs. The cat was diagnosed with Chronic kidney disease. This case was treated with administration Claneksi dan Doxycycline as antibiotic, antiparasitic drugs (Praziquantel, Pyrantel pamoate), and additional supplementation imboost, honey, fish oil and renal feed. Post treated the cat was presesnted to be better, Chronic kidney disease is not curable so that the necessary medication management and proper diet in order to improve the quality of life and prolong the life of the animal.

(C)2021. Prudenta et al. Open access under CC BY - SA license, doi: 10.20473/mkh.v32i1.2021.29-39

Received: 14-12-2020, Accepted: 28-01-2021, Published online: 29-01-2021

Available at https:/ / e-journal.unair.ac.id/MKH/index
\end{abstract}


Keywords: Chronic Kidney Disease, clinical signs, treatment, diet

\section{PENDAHULUAN}

Anjing adalah mamalia karnivora yang mempunyai kedekatan baik dengan manusia, karena mudah dilatih, diajak bermain, tinggal bersama, bersosialiasi serta naluri alami yaitu berkelompok. Pemilik anjing sangat menghargai nilai kesetiaan dan pengabdian anjing sehingga menganggap sebagai keluarga (Budiana, 2007). Berdasarkan taksonomi, anjing tergolong dalam ordo Carnivora dan temasuk keluarga Canidae. Famili Canidae ini dibagi menjadi 4 grup yaitu Canis (grup anjing), Vulpes (grup rubah, kecuali rubah abu-abu), Dusycyon (grup culpeo), dan Bush dog (mencakup jenis anjing lainnya). Anjing termasuk dalam genus Canis, satu genus dengan wolf (serigala), coyote, jackal dan dingo (Evans, et al. 2010).

Chronic Kidney Disesase (CKD) menurut Polzin (2011) adalah penurunan atau hilangnya kemampuan ginjal mengekskresi produk-produk tidak terpakai, mengkonsentraskan urin dan mengkonversi elektrolit. Penyakit ginjal kronis biasanya berlangsung dalam jangka waktu lebih dari 3 bulan. Penyakit ginjal kronis tergolong progresif dan irreversible dimana tubuh gagal untuk mempertahankan cairan elektrolit, sehinga menyebabkan uremia (Bargman dan Skorecki, 2013).

Terapi penyakit ginjal kronis didasarkan gejala-gejala klinis yang muncul dan ditujukan untuk mengurangi penderitaan diantranya yaitu terapi cairan (Wellman dkk., 2012), kalsitriol (Polzin dkk., 2005), ACE inhibitor, hormon eritropoietik, suplemen potassium, suplementasi antioksidan, terapi alkalin, dan diet pakan low protein. Tujuan utama pembatasan pemberian diet adalah untuk memenuhi kebutuhan energi, menghilangkan dampak uremia, meminimalisir gangguan 
keseimbangan cairan tubuh, elektrolit,

vitamin, mineral dan asam basa. Penyakit ginjal kronis tergolong irreversibel dan tidak dapat disembuhkan sehingga tujuan pemberian terapi adalah untuk memperbaiki kualitas hidup dan memperpanjang hidup hewan (McLeland dkk., 2014).

\section{Studi Kasus}

Seekor kucing jantan ras Domestic Short Hair (DSH) bernama Baim dengan berat badan $2,15 \mathrm{~kg}$, umur 3 tahun dibawa ke Rumah Sakit Hewan Pendidikan Universitas Brawijaya pada tanggal 4 September 2020 dengan gejala adanya anoreksia, letargi, dehidrasi, polidipsi, polyuria, dan pucat.

Tabel 1 : Pemeriksaan Hematologi Darah

\begin{tabular}{lccc}
\hline Parameter & Satuan & Normal & Hasil \\
\hline $\mathrm{Hb}$ & $\mathrm{g} / \mathrm{dl}$ & $9.5-1.5$ & $\mathbf{7 . 0}$ \\
$\mathrm{HCT}$ & $\%$ & $29-45$ & $\mathbf{2 3 . 6}$ \\
$\mathrm{RBC}$ & $10 \mathrm{x}$ & $6.0-10.0$ & $\mathbf{4 . 2 7}$ \\
& $6 / \mathrm{mm}^{3}$ & & \\
& & & \\
& &
\end{tabular}

\begin{tabular}{lccc}
\hline WBC & $10 \times 3 / \mathrm{mm}^{3}$ & $5.5-19.5$ & $\mathbf{2 4 . 1}$ \\
MCV & $\mathrm{Fl}$ & $41-54$ & $\mathbf{5 5 . 5}$ \\
MCH & $\mathrm{Pg}$ & $13.3-17.5$ & $\mathbf{1 6 . 3}$ \\
MCHC & $\%$ & $31-36$ & $\mathbf{2 9 . 6}$ \\
PLT & $10 \times$ & $150-600$ & $\mathbf{1 2 3}$ \\
& $3 / \mathrm{mm}^{3}$ & & \\
Neutrophil & $\%$ & $35-75$ & $\mathbf{8 6 . 8}$ \\
s & & & \\
Lympocyte & $\%$ & $20-55$ & $\mathbf{1 0 . 6}$ \\
s & & & \\
Monocytes & $\%$ & $1-4$ & $\mathbf{2 . 6}$ \\
Eosinophil & $\%$ & $2-12$ & $\mathbf{9 . 4}$ \\
PCT & & & $\mathbf{1 2 . 2}$ \\
PDW & & & \\
\hline
\end{tabular}

Tabel 2. Uji kimia darah BUN dan Kreatinin

\begin{tabular}{ccc}
\hline Parameter & Normal & Hasil \\
CRT & $0.4-1.8 \mathrm{mg} / \mathrm{dL}$ & $\mathbf{4 . 9 2}$ \\
BUN & $7-27 \mathrm{mg} / \mathrm{dL}$ & 52 \\
& & \\
Hasil & pemeriksaan & fisik \\
menunjukkan, body condition score & (BCS)
\end{tabular}


2/5, frekuensi nafas $12 \mathrm{kali} /$ menit, frekuensi pulsus 140 kali/menit, suhu $37.4^{\circ} \mathrm{C}$, turgor $>3$ detik, CRT $>2$ detik, selaput lendir (SL) berwarna pucat. Pada hidung terlihat ada discharge nasal keruh kehijauan dengan konsistensi kental.

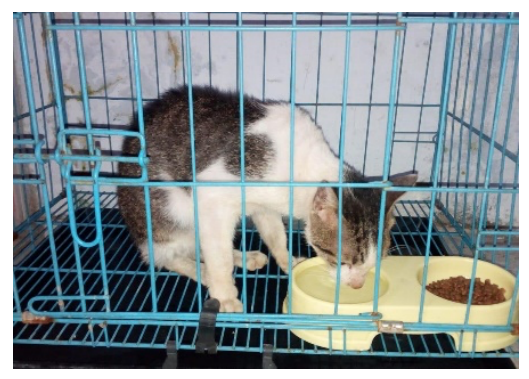

Gambar 1. Kucing Baim

Penurunan $\mathrm{RBC}, \mathrm{Hb}$, dan $\mathrm{HCT}$ adalah indikator anemia. Temuan umum anemia karena penurunan distribusi oksigen yaitu mukosa pucat (pink pale), takikardia, depresi dan denyut nadi lemah. Jenis anemia makrositik hipokromik dengan penurunan hematokrit dan kadar hemoglobin dikaitkan dengan perdarahan internal maupun eksternal, sirosis, gangguan hipertiroid, defisiensi zat besi, anemia bersifat regeneratif yang disebabkan hemoragi maupun hemolisis, hal tersebut berkaitan dengan siklus sel darah merah, dan tidak ada kelainan pada hematopoesis.

Menurut hadil uji hematologi, kucing Baim terdapat penurunan $\mathrm{RBC}, \mathrm{Hb}$, dan HCT menandakan bahwa kucing Baim mengalami kondisi anemia. Penurunan HCT menunjukkan presentase jumlah sel darah merah yang beredar pada sirkulasi dan didukung dengan penurunan jumlah sel darah merah total. Penurunan hemoglobin selaras dengan penurunan jumlah total sel darah merah sehingga kondisi anemia terlihat pada gejala klinis yang muncul yaitu anemia dimana pada mukosa tubuh terlihat pucat (Latimer, 2011).

Leukositosis, peningkatan WBC diikuti peningkatan komponennya sperti granulositosis sebagai respon infeksi dan inflamasi maka produksi dalam sirkulasi meningkat, reaksi hormonal (aktifitas fisik meningkat, trigger rasa takut); nekrosis jaringan dan organ, hemolysis (internal atau 
eksternal), gangguan imun; Kondisi trombositopenia kucing Baim mengarah pada destruksi trombosit yang bisa disebabkan adanya infeksi, sirosis, acute renal failure, penyakit imun, penggunaan obat tertentu.

Neutrofilia, peningkatan jumlah neutrophil darah, disebabkan oleh infeksi, kebutuhan jaringan pada fagositosis sel debris dan agen penyebab, faktor stress, pembebasan kortikosteroid endogen oleh rasa nyeri, anestesi, pascaoperasi, trauma, neoplasia, hiperadrenokortism.

Limfopenia adalah penurunan jumlah limfosit darah, adanya obstruksi (saluran cerna, saluran urinasi, respirasi dan empedu), hambatan limfopoesis, penyakit endokrin.

Hasil uji kimia darah berupa BUN dan kreatinin menunjukkan ada peningkatan keduanya sehingga memicu kondisi azotemia. Peningkatan kreatinin dalam datah mengarah pada gangguan sekresi kreatinin seperti pada ginjal, otot, jantung dan gangguan sirkulasi. Sering dikaitkan dengan gagal ginjal akut (GGA) maupun kronis (GGK), penurunan laju filtrasi meningkatkan kreatinin serum, kemungkinan lain yang dapat terjadi adanya penyakit metabolik seperti nephropathy diabetic (mengalami gejala klinis polidipsi dan poliuria).

Azotemia dikategorikan menjadi tiga yaitu prerenal, renal, dan postrenal. Azotemia prerenal dapat disebabkan oleh peningkatan katabolisme dari total asupan protein dan penurunan perfusi ginjal sehingga dapat meningkatkan berat jenis urin. Azotemia renal muncul ketika 3/4 atau sekitar $75 \%$ nefron telah kehilangan fungsi dan ditandai dengan peningkatan BUN dan Kreatinin dalam jumlah besar. Kondisi azotemia renal dan prerenal dapat terjadi secara bersamaan dan berat jenis urin pada kondisi azotemia renal bisa dalam rentang normal maupun terjadi perubahan. Azotemia postrenal ditandai adanya kondisi oligouria atau anuria yang 
disebabkan oleh obstruksi, ruptur tractus urinari. Berat jenis urin pada kondisi azotemia postrenal dapat bervariasi dari rentang normal hingga abnormal. Kondisi azotemia postrenal akan hilang setelah dilakukan perbaikan terhadap gangguan yang dialami hewan (Latimer, 2011).

\section{Terapi}

Terapi kucing dengan kondisi (Chronic Kidney Disease) CKD adalah dengan mengurangi gejala uremia, status hidrasi, gangguan gastrointestinal, hyperphospatemia, asidosis, hipokalemia/hiperkalemia, anemia, proteinuria, hipertensi, dan hiperparatiroidisme sekunder (Foster, 2013). Terapi obat yang diberikan kepada kucing Fluimicin dan Claneksi dikarenakan kucing mengalami bersin. Pemberian Fluimucil pada kucing sebanyak 20-25 $\mathrm{mg} / \mathrm{KgBB}$ terapi dilakukan selama dua minggu, Fluimucil berfungsi untuk mengobati penyakit saluran pernapasan,

Acetylcysteine adalah obat yang berfungsi mengencerkan mukus pada penyakit saluran pernafasan dan merupakan obat agen mukolitik yang juga dikenal sebagai $\mathrm{N}$-acetylcysteine atau N-acetyl-L-cysteine (NAC). Sebagai agen mukolitik, acetylcysteine bekerja dengan memecah serat asam mukopolisakarida yang membuat mukus lebih encer dan mengurangi adhesi mukus dinding tenggorokan (Saito, 2010).

Antibiotik yang diberikan pada kucing berupa Claneksi sebanyak 62,5 $\mathrm{mg} / \mathrm{KgBB}$ yang diberikan selama dua minggu. Claneksi adalah obat antibiotik berupa kombinasi Amoxicillin dan Clavulanic Acid. Amoxicillin bekerja menghambat sintesis peptidoglikan sehingga bakteri mengalami lisis dan mati. Sementara itu Clavulanic Acid merupakan substansi yang menghambat pembentukan beta-laktamase yang diproduksi bakteri untuk melindungi dirinya dari serangan yang mengandung acetylcysteine. antibiotik tipe penisilin seperti amoxicillin. (c)2021. Prudenta et al. Open access under CC BY - SA license, doi: 10.20473/mkh.v32i1.2021.29-39 Received: 14-12-2020, Accepted: 28-01-2021, Published online: 29-01-2021 Available at https:/ / e-journal.unair.ac.id/MKH/index 
Amoxicillin dan Clavulanic Acid ini membuat co amoxiclav ampuh mengatasi serangan bakteri dari berbagai jenis termasuk juga bakteri yang resisten terhadap amoxicillin (Birchard dan Sherding, 2000).

Terapi suportif yang diberikan berupa Imboost, Hematodin $\AA^{\circledR}$ Squalene ${ }^{\circledR}$ dan Madu. Imboost mengandung Echinacea extract sebagai immunomodulator (Wiestarsih dkk., 2018). Hematodin ${ }^{\circledR}$ berfungsi sebagai multivitamin dan hematopoietin dengan indikasi pemberian pada hewan dengan gangguan hematopoesis. Hematodin ${ }^{\circledR}$ adalah obat golongan antianemik untuk membantu proses regenerasi sel darah merah (Chrisnanta dan Fitri, 2018; Kementerian Pertanian RI, 2017). Squalene ${ }^{\circledR}$ berfungsi menambah nafsu makan secara signifikan, dan meningkatkan sistem kekebalan tubuh (Undjung, 2015). Madu berfungsi menambah selera makan sehingga kucing mempunyai kecukupan energi baik (Sitohang, 2011).

\section{PEMBAHASAN}

Gejala CKD pada umumnya adalah poliuria dengan polidipsia kompensatorik, anoreksia, lethargi, kakheksia, dan yang jarang ditemui pada awal CKD tetapi umum pada fase perkembangan lanjutan penyakit yaitu gangguan gastrointestinal. Pemeriksaan fisik hewan CKD menunjukkan penurunan massa otot akibat status nutrisi, murmur jantung akibat kondisi anemia, hipertensi, dehidrasi karena hilangnya cairan pada poliuria dan perubahan ukuran serta bentuk dari organ ginjal dengan ada tidaknya rasa sakit. Pemeriksaan perektal dilakukan untuk mengetahui apakah pasien mengalami melena maupun hematochezia sebagai indikator gangguan gastrointestinal akibat ulkus uremikus (Foster, 2013). 
Tabel 3. Perbedaan AKI dan CKD

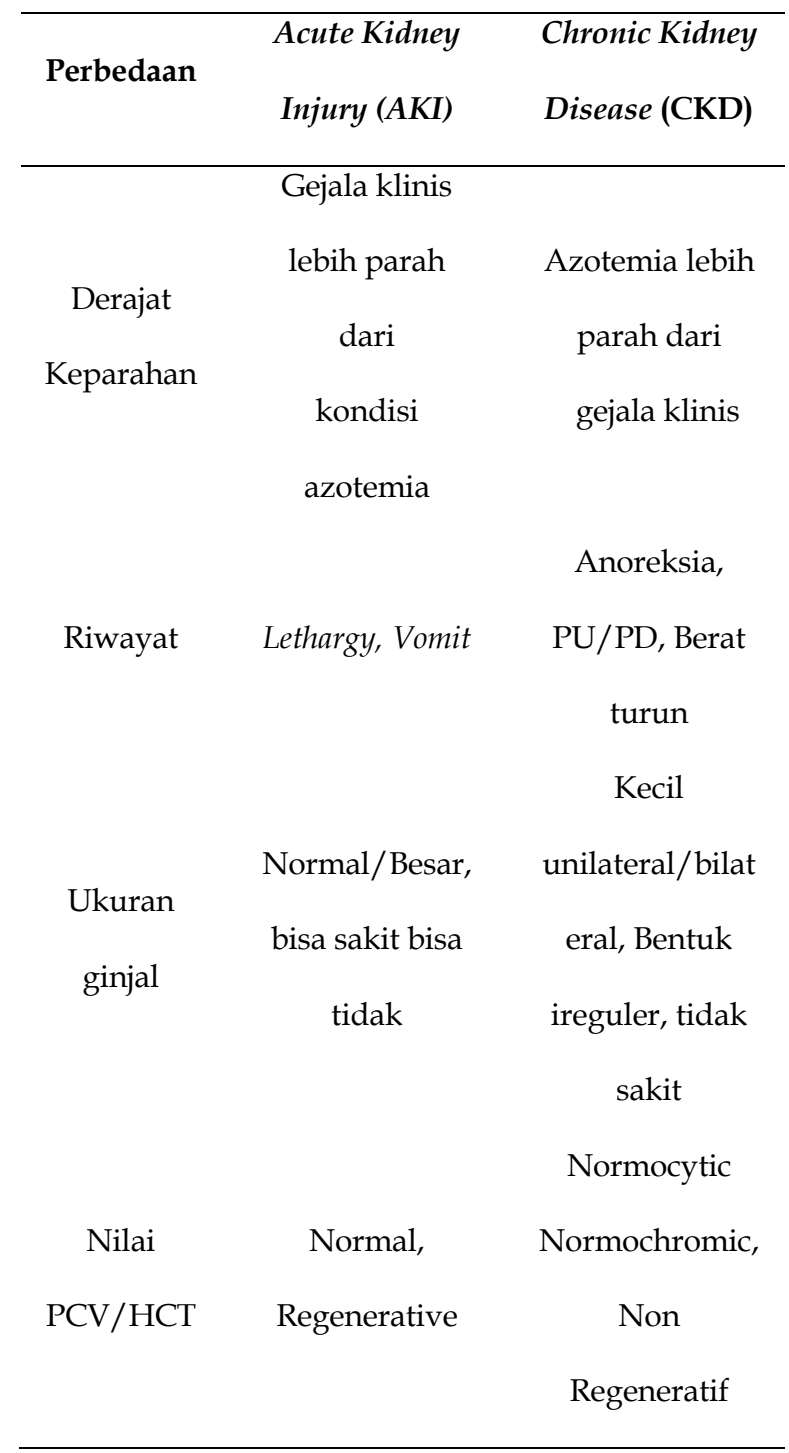

Chronic kidney disease (CKD) atau

disebut penyakit gagal ginjal kronis merupakan kelainan anatomis dan atau fungsional dari satu atau kedua ginjal yang muncul dalam jangka waktu lama, irreversibel dan tergolong sebagai manifestasi akhir dari berbagai macam penyakit (Lawson et al., 2015).

Kucing Baim telah memasuki kondisi azotemia tetapi tidak ada respon sakit pada saat palpasi ginjal. Kondisi anoreksia, PUPD, serta anemia menunjukkan adanya gangguan proses hematopoesis dan sistem ekskresi sehingga hal ini mengarah pada Chronic Kidney Disease.

Kondisi kucing Baim tergolong pada kategori CKD stadium III karena kadar serum kreatinin 2.9-5.0 mg/dL yaitu 4.78 mg/dL. Pada stadium ini, azotemia sedang dengan gejala ekstrarenal muncul di awal, sedangkan gejala sistemik muncul di akhir secara signifikan.

Perjalanan penyakit CKD sendiri dapat mengakibatkan anemia, hipertensi sistemik, dan penurunan fungsi ginjal (Pelander, 2008). Kucing Baim mengalami kondisi anemia yang dapat disebabkan oleh defisiensi eritropoietin yang dihasilkan organ ginjal yang menginduksi 
pembentukan eritrosit (Salasia dan Hariono, 2014). Anemia pada kondisi CKD juga dapat disebabkan oleh terjadinya kerapuhan membran sel darah merah akibat uremia (Pelander, 2008). Asidosis adalah salah satu penyebab rapuhnya eritrosit, Kuzman et al. (2000) menyebutkan bahwa $\mathrm{pH}$ berpengaruh terhadap kelenturan membran sel darah merah. Kondisi azotemia dengan penumpukan ureum dapat menyebabkan iritasi pada mukosa tubuh yang ditemui pada kucing Baim berupa stomatitis. Perlukaan pada mukosa salah satunya saluran gastrointestinal juga dapat menyebabkan terjadinya anemia dengan perdarahan jangka panjang (Pelander, 2008).

Pada kucing Baim terdapat gejala bersin, Terapi yang diberikan adalah melalui pemberian Fluimucil dan Claneksi. Fluimucil berfungsi mengobati penyakit pada saluran pernapasan, yang mengandung acetylcysteine sebagai obat mukolitik pada penyakit saluran pernafasan dan merupakan obat agen mukolitik yang juga dikenal sebagai $\mathrm{N}$-acetylcysteine atau $\mathrm{N}$-acetyl-L-cysteine (NAC). Sebagai agen mukolitik, acetylcysteine bekerja dengan cara memecah serat asam mukopolisakarida yang membuat mukus lebih encer dan mengurangi adhesi mukus pada dinding tenggorokan (Saito, 2010).

Claneksi adalah antibiotik kombinasi Amoxicillin dan Clavulanic Acid. Amoxicillin bekerja dengan menghancurkan peptidoglikan yang merupakan pelindung dinding sel bakteri. Saat bakteri membelah diri, amoxicillin bekerja menghambat pembentukan peptidoglikan dan bakteri mengalami lisis dan mati. Sementara itu Clavulanic Acid merupakan substansi yang dapat menghambat pembentukan betalaktamase yang diproduksi bakteri untuk melindungi dirinya dari serangan antibiotik tipe penisilin seperti amoxicillin. Gabungan amoxicillin dan Clavulanic Acid ini membuat co amoxiclav ampuh mengatasi serangan bakteri dari berbagai jenis 
termasuk juga bakteri yang resisten terhadap amoxicillin (Birchard dan Sherding, 2000).

\section{KESIMPULAN}

Chronic Kidney Disease (CKD) adalah penyakit ginjal karena kehilangan kemampuan ginjal dalam memfiltrasi produk tidak terpakai dalam tubuh. Terapi yang dapat diberikan adalah dengan Antibiotik kombinasi Amoxicillin dan Clavulanic acid, Fluimucil sebagai mukolitik, dan terapi suortif berupa Imboost, Hematodin $\AA$, Squalene $\AA$ dan Madu.

\section{SARAN}

Perlu dilakukan kontrol terhadap diet, seperti yang dianjurkan oleh Foster (2013) yaitu diet pada pasien CKD harus rendah protein, phospor, dan sodium, tetapi tinggi vitamin B, serat, dan asam lemak omega-3 serta diberikan pakan renal.

\section{DAFTAR PUSTAKA}

Bargman, J. M., Skorecki, K. 2013. Chronic Kidney Disease. In: Jameson J L, Loscalzo J (eds). Horrison's Nephrology and Acid Base Disorders. McGraw-Hill. New York. 113

Birchard, S. J. and Sherding, R. G. 2000. Saunders Manual of Small Animal Practice. New York, USA : WB Saunders

Chrisnanta, K. W. dan A. D., Fitri. 2018. Tracheotomy pada anjing American Pit Bull Terrier yang mengalami vulnus morsum. Veterinary Letters 2 (4):69 70

Foster, J. D. 2013. Canine Chronic Kidney Disease: Current Diagnostics \& Goals for Long-term Management. Today's Veterinary Practice: $21-26$.

Latimer, K. S. 2011. Duncan and Prasse's Veterinary Laboratory Medicine: Clinical Pathology 5th Edition. Iowa: John Wiley \& Sons, Inc.

McLeland, S.M., Lunn, K.F., Duncan, C.G., Refsal, K.R. and Quimby, J.M. 2014. Relationship among serum creatinine, serum gastrin, calcium-phosphorus product, and uremic gastropathy in cats with chronic kidney disease. J. Vet.Intern. Med. 28: 827-837.

Pelander, Lena. 2018. Chronic Kidney Disease in the Dog: Pathophysiogical mechanismas and diagnostic aspects. Faculty of Veterinary Medicine and Animal Science. Departement of Clinical Science. Swedish University of Agricultural Sciences.

Polzin, D.J., Ross, S. and Osborne, C.A. 2009. Kalsitriol. In: Bonagura J.D. \& Twedt D.C. (Eds), Kirk's Current Veterinary Therapy. XIV. Saunders Elsevier, St Louis, Missouri. : 892-895.

Saito, C., Zwingmann, C., dan Jaeschke, H. 2010. Novel Mechanisms of Protection Against Acetaminophen

Hepatotoxicity in Mice by Glutathione 
and NAcetylcysteine.

Hepatology. Vol. 51 (1): 246254.Freund, Jan. 2016. Extrarenal manifestations of uremia in a keeshond with juvenile nephropathy.

Faculty of Veterinary Medicine. Ghent University.

Sitohang, H. T. Pengaruh pemberian madu terhadap gambaran histologi testis mencit (mus musculus) yang diberi plumbum asetat [Skripsi]. Medan: Universitas Sumatra Utara.

Wellman, M. L., DiBartola, S. P. and Kohn, C. W. 2012. Applied physiology of body fluids in dogs and cats. In: DiBartola SP, ed. Fluid, electrolyte, and acid-base disorders in small animal practice. 4th ed. St. Louis (MO): Elsevier Saunders :15.

Wiestarsih, L., Prasetyo, B. F., Madyaastuti, R., Noviyanti, L., Akbari, R. A. 2018. Obat-Obatan Untuk Hewan Kecil. IPB Press. Bogor 